\title{
UNITED STATES DEPARTMENT OF THE INTERIOR GEOLOGICAL SURVEY
}

PAPATAPINARY GEOMAGNETIC DATA

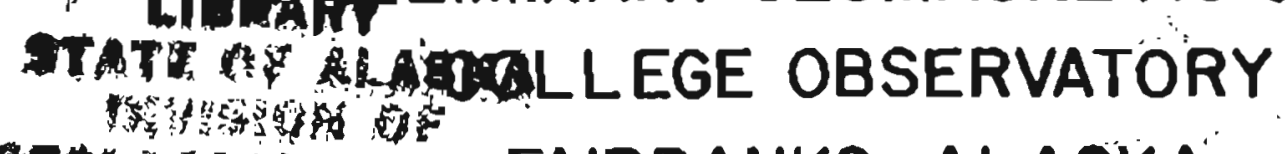
GEALT:

JANUARY 1981

OPEN FILE REPORT

$81-300 A^{\circ}$

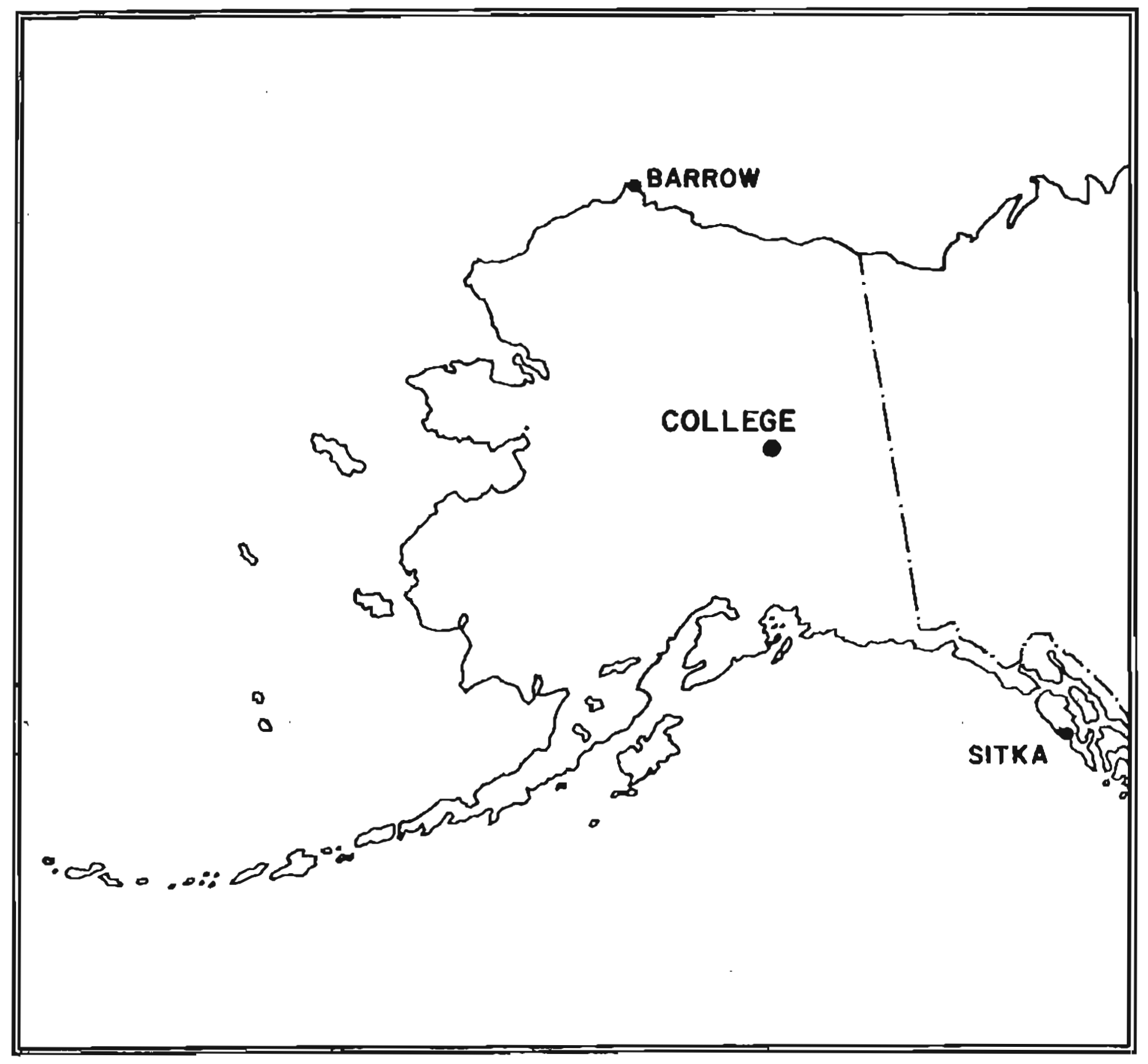




\section{ORDER OF CONTENTS}

Explanation of Data \& Reports

Magnetic Activity Report

Outstanding Magnetic Efrects

Principal Magnetic Storms

Preliminary Calibration Data \& Monthy Mean Absolute Values

Magnetogram Hourly Scalings

Sample Format for Normal \& Storm Magnetograms

Normal Magnetograms

Storm Magnetograms (When Norma1 is too disturbed to read) 
THIS REPORT WAS PREPARED UNDER THE DIRECTION OF JOHN B. TOWNSHEND', CHIEF OF THE COLLEGE OBSERVATORY WITH THE ASSISTANCE OF OBSERVATORY STAFF MEMBERS J,E, PAPP, E. A. SAUTER. AND S.P, TILTON, AND IN COOPERATION WITH THE GEOPHYSICAL INSTITUTE OF THE UNIVERSITY OF ALASKA, THE COLLEGE OBSERVATORY IS A PART OF THE BRANCH OF ELECTROMAGNETISM AND GEOMAGNETISM OF THE U.S. GEOLOGICAL SURVEY.

INTRODHCTION

The prellninary goomagnetic dota ineluded hart is made apaliabla to selentific personnel end orgenizations, as part or a cosperative effort and on data exohange basis beousse of the early need by some uaers. To avoid delay, ald of the data is copied from orlgtral forms or"cessed at tho observatory; thereiore it gbould be regarded as prellminary. Inquiries about this report or aboist the College Obzervatory ahould be addressed to: Chder, College Observatory

J.s. Goologiegl survey

Yukon: Drtve on Wast Ridge

Falroanis, diagka 99701

Requests for coples of the magnetograms excopt for the curront month should be addressed to:

Wor id Data Cencer A-NOAA

Enstisonuental De ta Service

Boulder, Colorsdo 80302

\section{GECAMGNETIC DATA}

Normal, Storm, and Rapid Run magnetograms and approprlate calloration data are pracessed dally at the observatory and are available for analysis or copying. Also available are mean hourly scalines, $K$-Ind1ces, selscted magnetic phenomena reports, and on a real-time basig are recordings from a 3-component fluxgate magnetometer and F-component proton magnetorder.

\section{Magnetic Actio1tj}

The K-tadex The $k$-Index is a logarl thm 0 measure ment of the range of the mast disturied component ( $D$ or i) of the peomegatic rield for eight intervats beginniog 0000-0300, 030060600...2100-2100 UT. It la a measure of the differsnce between the highest and lownest devistion fmon a smooth curve to be expected for a component on a magnetically quiet dsy, within a three hour interval. The Equivalent da11y amplitude, AK. The K-Index is converted lnio an equivalent range, ax, whioh is neer the eenter or the 1 lanting ganma ranges for a glvon $k$. The average of the alght values is called equivalent

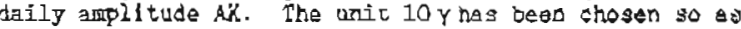
rot to pive the lllugion of an sccuracy not Juselrted. The schedule t'or converting gamsen range to $K$, and $K$ to 9 k is as collows:

\begin{tabular}{|c|c|c|c|}
\hline Genms & PADge & K- Index & $8 x^{*}$ \\
\hline 8 & $<-23$ & 0 & $\overline{0}$ \\
\hline 25 & $<50$ & 1 & 3 \\
\hline 30 & $<100$ & 2 & 7 \\
\hline 100 & $<200$ & 1 & 15 \\
\hline 200 & $<y 50$ & 4 & 27 \\
\hline 330 & $<600$ & 5 & 48 \\
\hline 600 & $<1000$ & 6 & 80 \\
\hline 1000 & $<1620$ & 7 & $1<0$ \\
\hline $16>0$. & $<2500$ & 8 & 240 \\
\hline $2500+$ & & 9 & 400 \\
\hline
\end{tabular}

The Magnelic Daliy Character Figure, C. To each Universal day character is assigned on tho basts $C=0$, if 12 is quxat; $C=1$ is $i t$ is moderately disturbed; $C=2$ if ti 18 greatly disturbed. The method uaed io sssign sheracters ai the colloge cbservatory is based on $A K$ as follows:

\begin{tabular}{ll} 
AK Range & 0 \\
\hline $0 \approx 11$ & 0 \\
$11=50$ & $\frac{1}{20}$
\end{tabular}

floutlne asgignment ô $\mathrm{C}$ segs discontinued at College on Jaruery 1, 1976.
OESERVATORY LOCATYON

The College Observatory, operated by the U. S. Gologlosi Survey, is located at the Universits of Alaska, Folrbanks, Alaska. It is nosp tha Auroral zons and the northern limit of ine world's grastest earthquaxe belt, the circum-Pacirlc Salomic bali. Al though the observatory's basto operation is in geomagretises and selsmology, it cooperates with other solentists and organizstions in aress where the factllty and persomel can be of servict.

The obervatory is one of three sparated by the USGS in diaska. The others are loovted at Barrow and Sitka.

The position of the obaervatom ant is

Coographic latizude......6.6451.6.

geographic longitude........1<7058.2

Geomgnetie Iaxi uude....... 64.6

Geomagnetic longitude......,-256.50

blovation...............200 mevers

Selactod Phenomena \& Outstanding Marmes: Er Electe

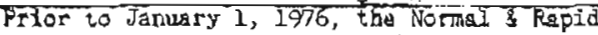
Run records were reviewed at the observatory lor gelected magnetic phenamena and the evonts identified mere forwarded to the IUCO Comolsston on Hegatic Variations and Disturbarices. Thlo s disoontinued on Janubry 1, 1976, but a report on Outstanalog Whotio Erfsets 1s prepared monthy for this report.

Prlacipel Magnetic Storma

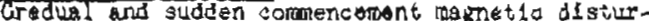
bances with ar least one K-Iadex of 3 ar greater, which sre belleved to be part of a world-wida disturbance, are classifled as principel magnetic storms. The time of the stom beginnirg and ending; direction and amplirude of gudden conmencements: portod o' maximum sctivity; and storm range gre reported. Lloninly reports of these date are forwerded to the world Data Center A in Bouldar, Colorado.

Naknotogran Hourly Scalings

Magnotogram hourly sealings are avorages for succossive periods of one hour for the $D, H$, and $Z$ elements. The value in the coluran haded " 01 " Is the average ior the hour beginning 000 and anding 0100 . Note that the velues on the scallng shoots are in tenths of wh the decimal point onlted. The usar of these acalings showld keep in mind that the tabular rglues are hourly mans and if he is intereated in the derailed norphology of the magoeric [leld, he should refer directly to the magnotograns.

\section{sagnerogryms}

ho nomal mognetoprams in thds raport gre reproduced at about one-tided the slze of the artalinals. Frelinizary bast-ilne values and scale valuas adopted for use wi th tbe original magnetograms are lncluded. For dege when the magnetic Pield is too disturbed for the Normal mangtogram to be reziabie, Storm magnetorams are reproduced.

Abrolutes, base-lines, and Scale Values

To deterine the absoiute value of the mgletic clald irom the bourly mears or irom point scaling the following equations should be ueed:

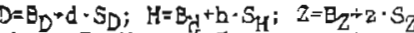
whera D, $H$, and $Z$ are ebsolute values; $B_{D}, B_{h}$ and $E_{2}$ are base-line values; $S_{D}, S_{A}$ and $S_{Z}$ are acale values; and $d, k$, and $z$ are seglings in latilineters. 


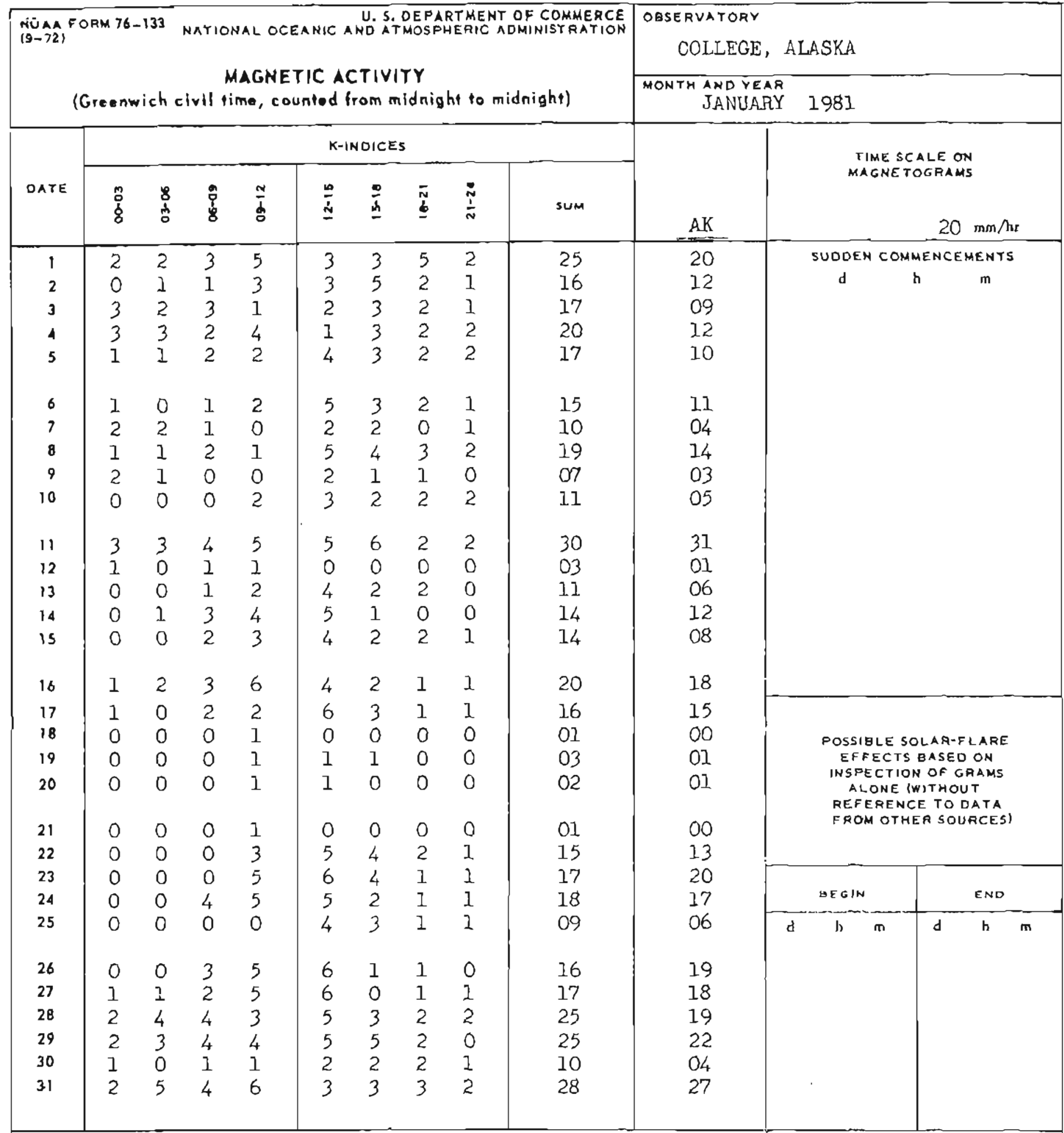

\begin{tabular}{|c|c|c|c|c|}
\hline \multirow{2}{*}{$\begin{array}{l}\text { K SEALE USEO: } \\
\text { LOWER LIMIT FOR } X=9 . \ldots \ldots .\end{array}$} & 0 & $H$ & $z$ & \multirow{3}{*}{$\begin{array}{l}(\mathrm{mm}) \\
(\mathrm{r} / \mathrm{mm})\end{array}$} \\
\hline & 683.8 & 321.7 & & \\
\hline \multirow{2}{*}{ CURRENT SCALE VALUE........ } & 3.75 & 7.81 & & \\
\hline & 2560 & 2510 & & (to ncarest $10 \gamma$ ) \\
\hline
\end{tabular}
SCALINGS ANO COMPUTATIONS HAVE BEEN CHECKED.

A PROVED JOHN B. TOWNSHEND, CHIEF, COLLEGE OBSERVATORY 


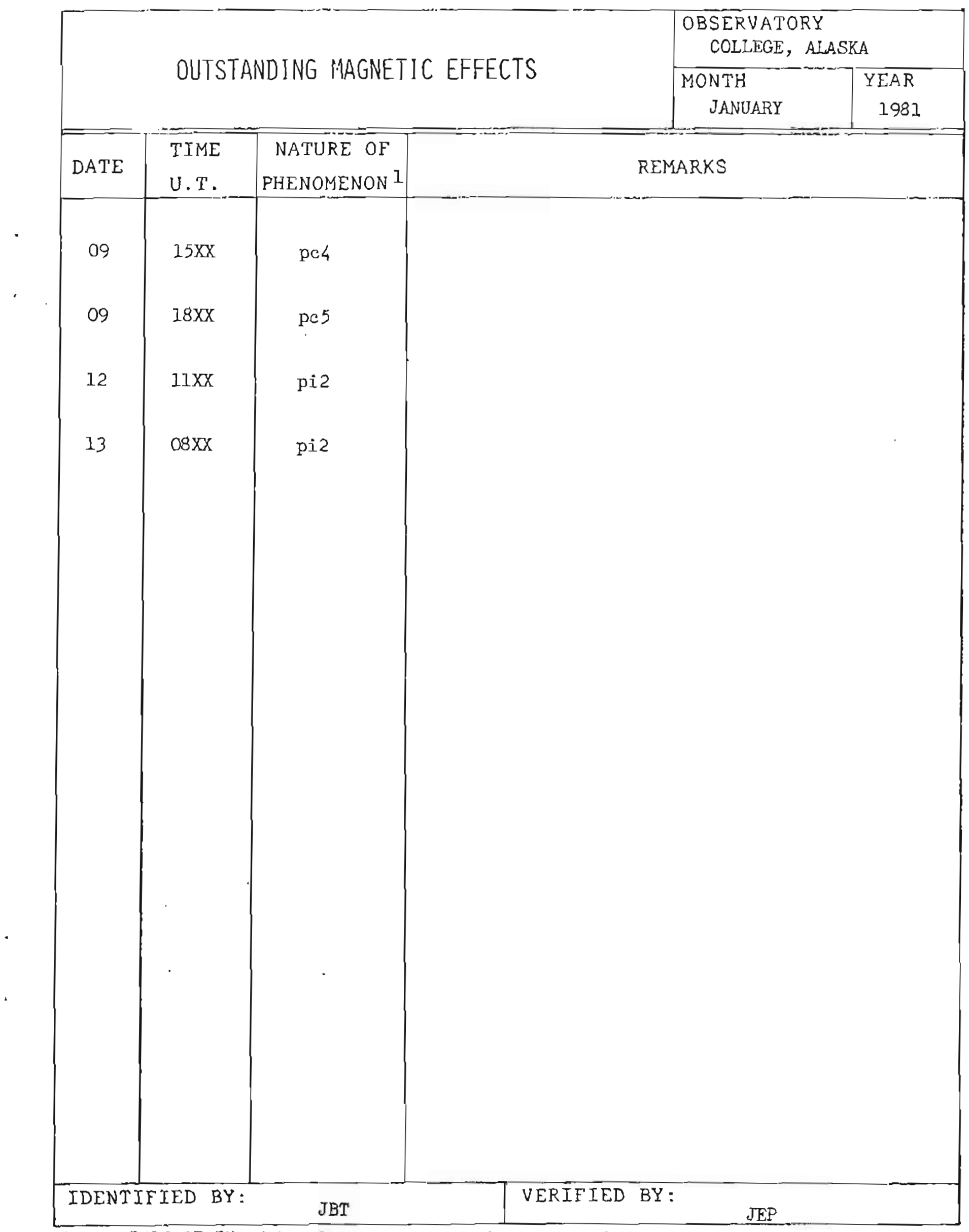

1. NATURE of PHENOMENON: ssc, ssc*, si, si*, b, bp, bs, bps, pcl, pc2 - - pc5, pg, pi l, pi 2, sre. 


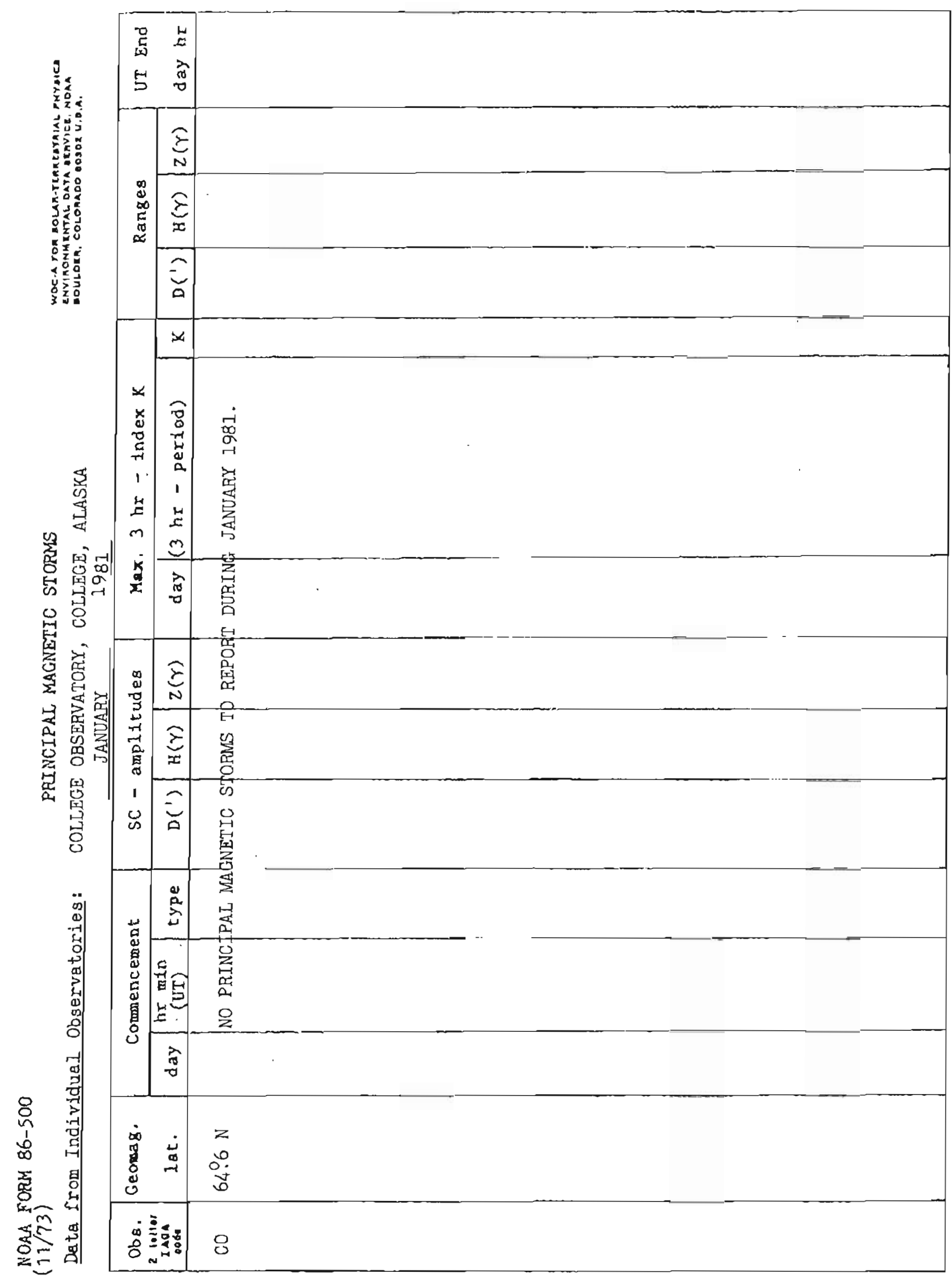




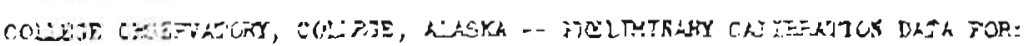

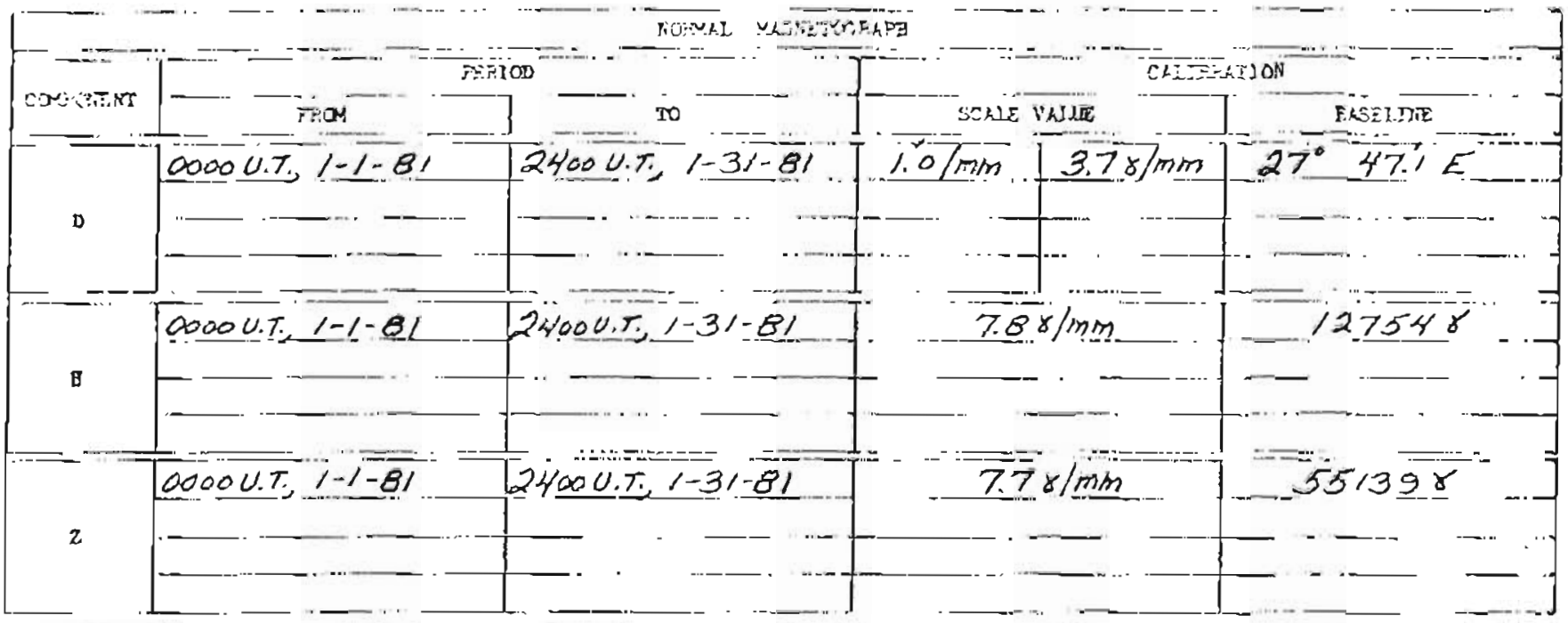
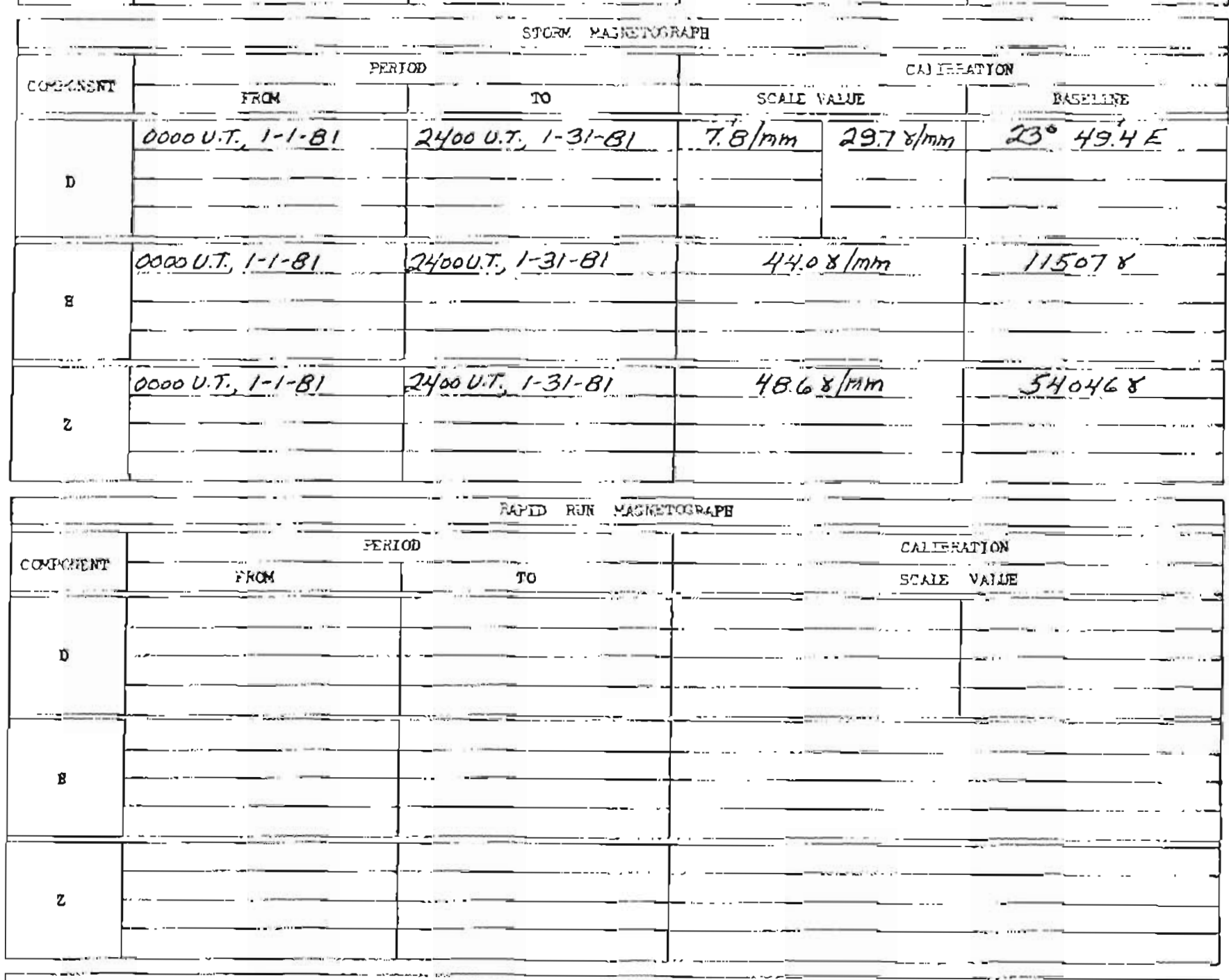

MONTHLY MEAN ARSOLTE VAUUES

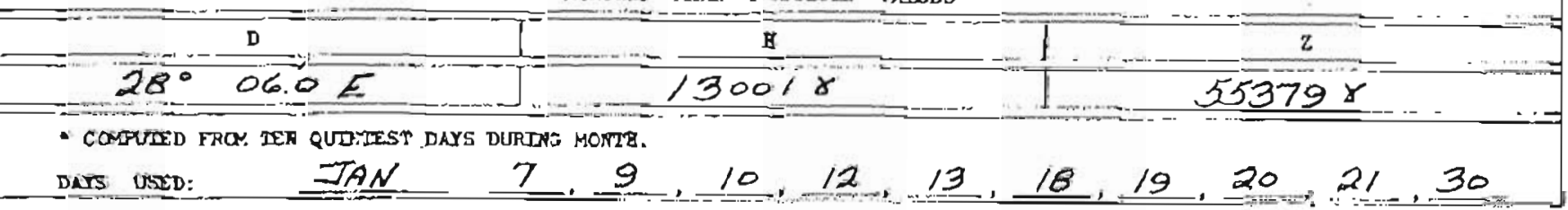




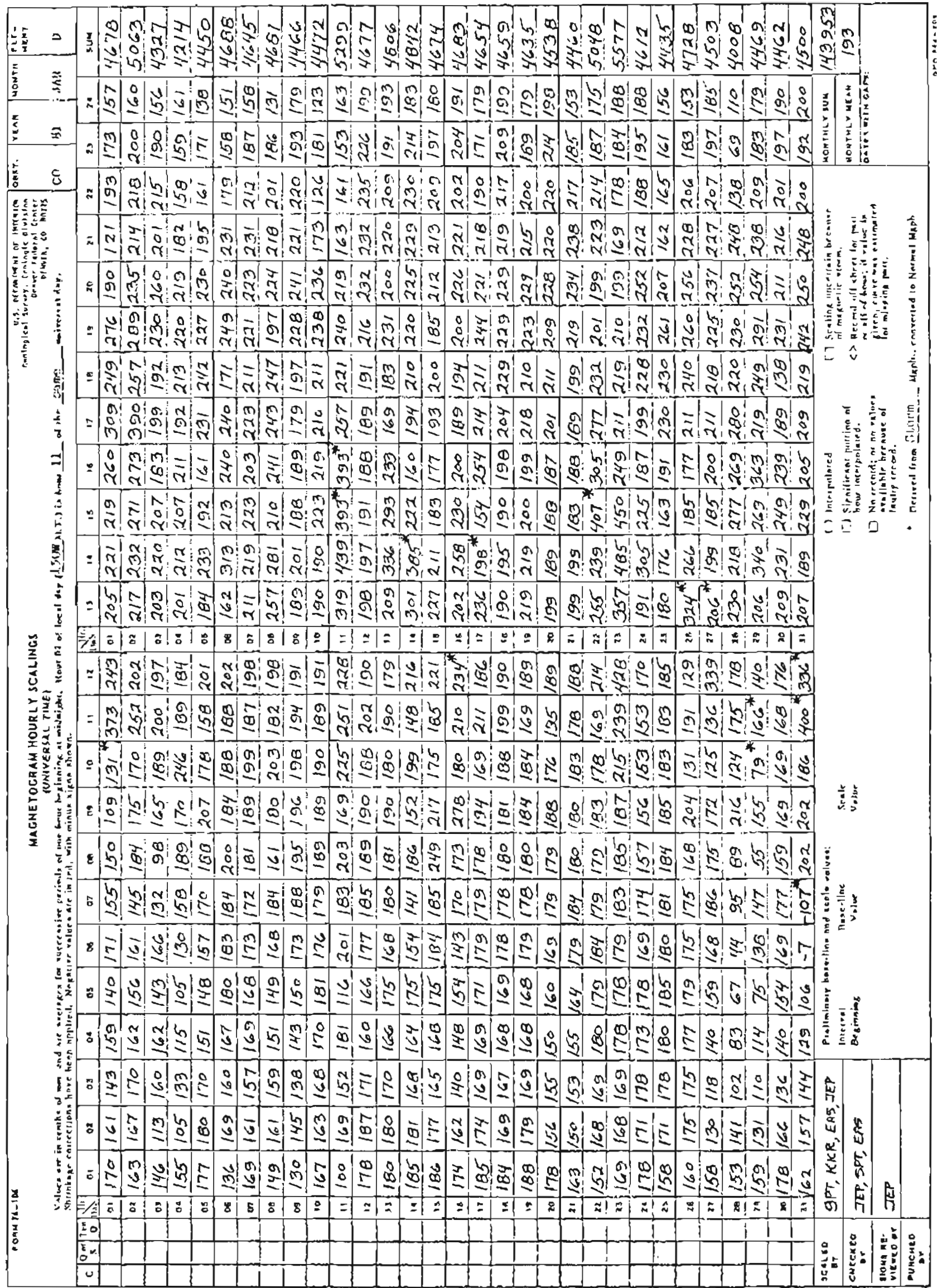




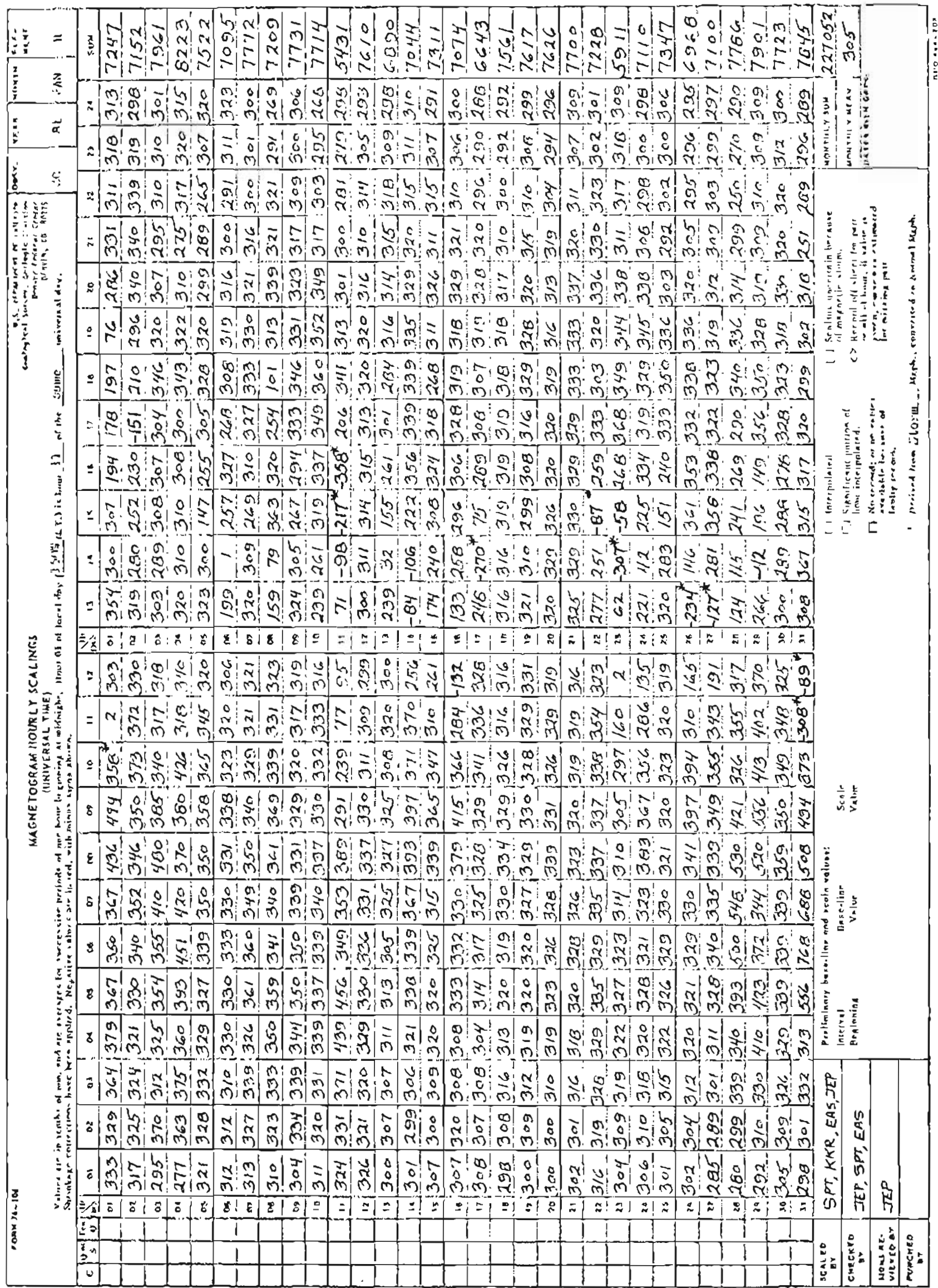




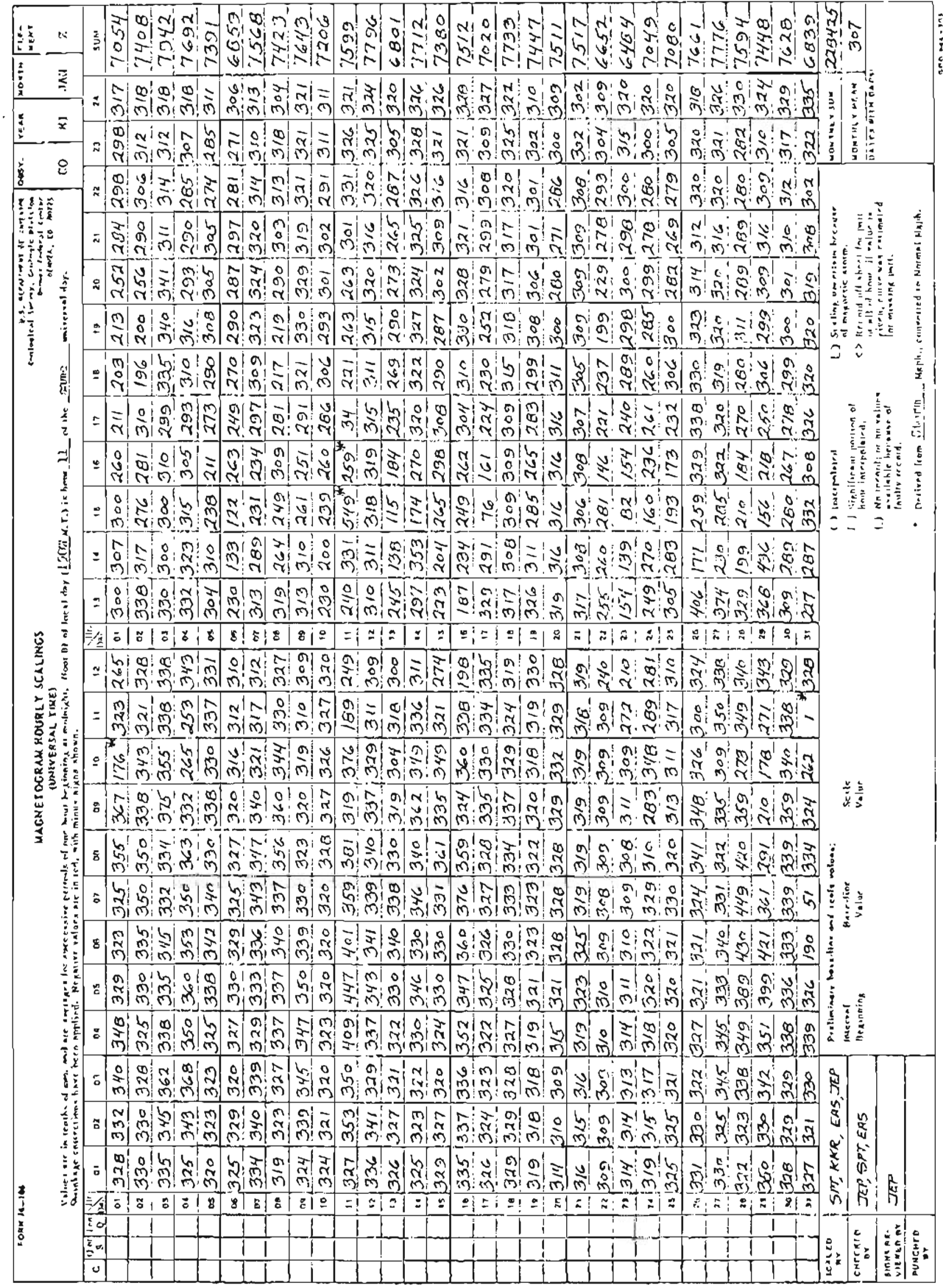




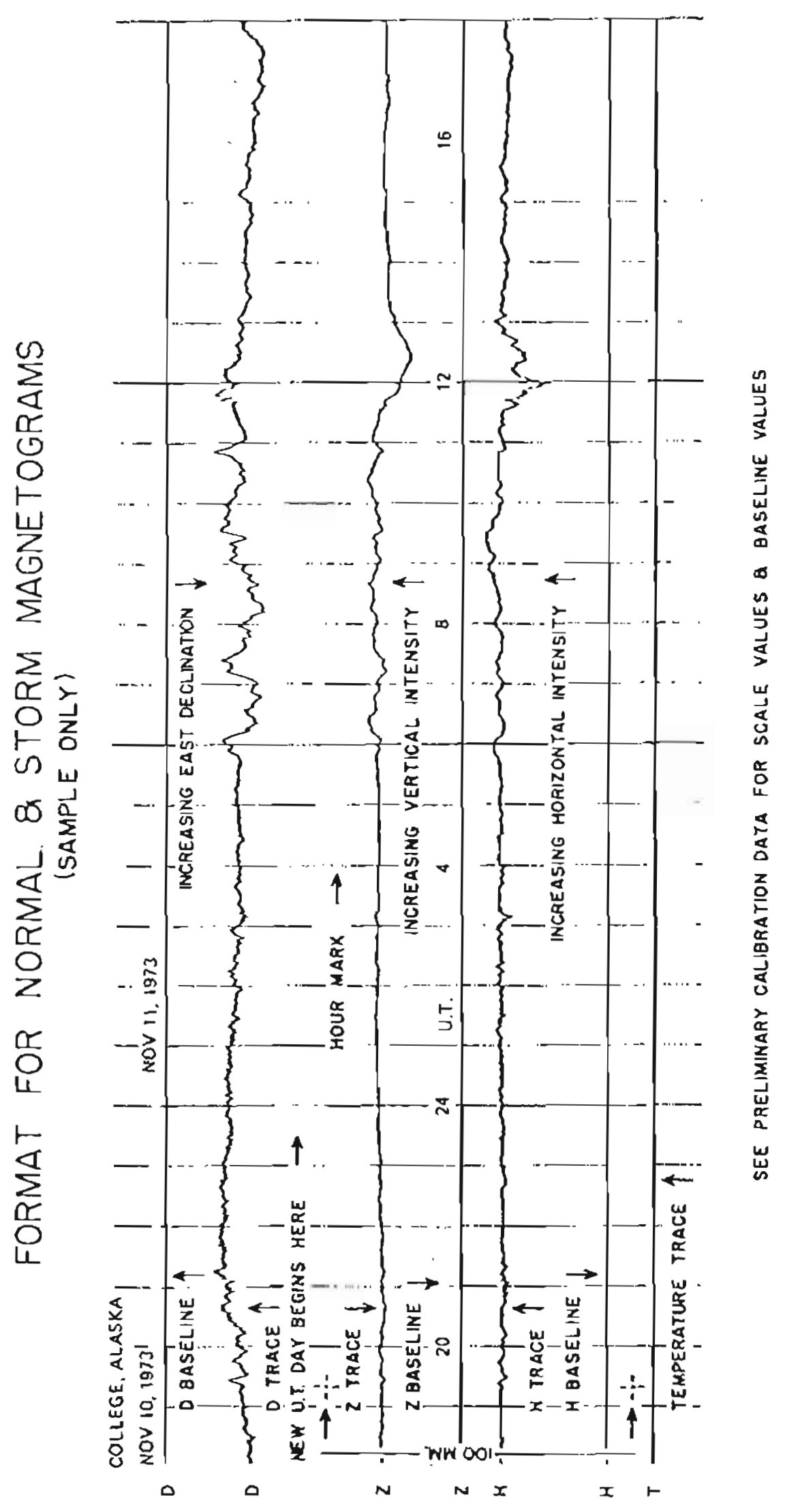




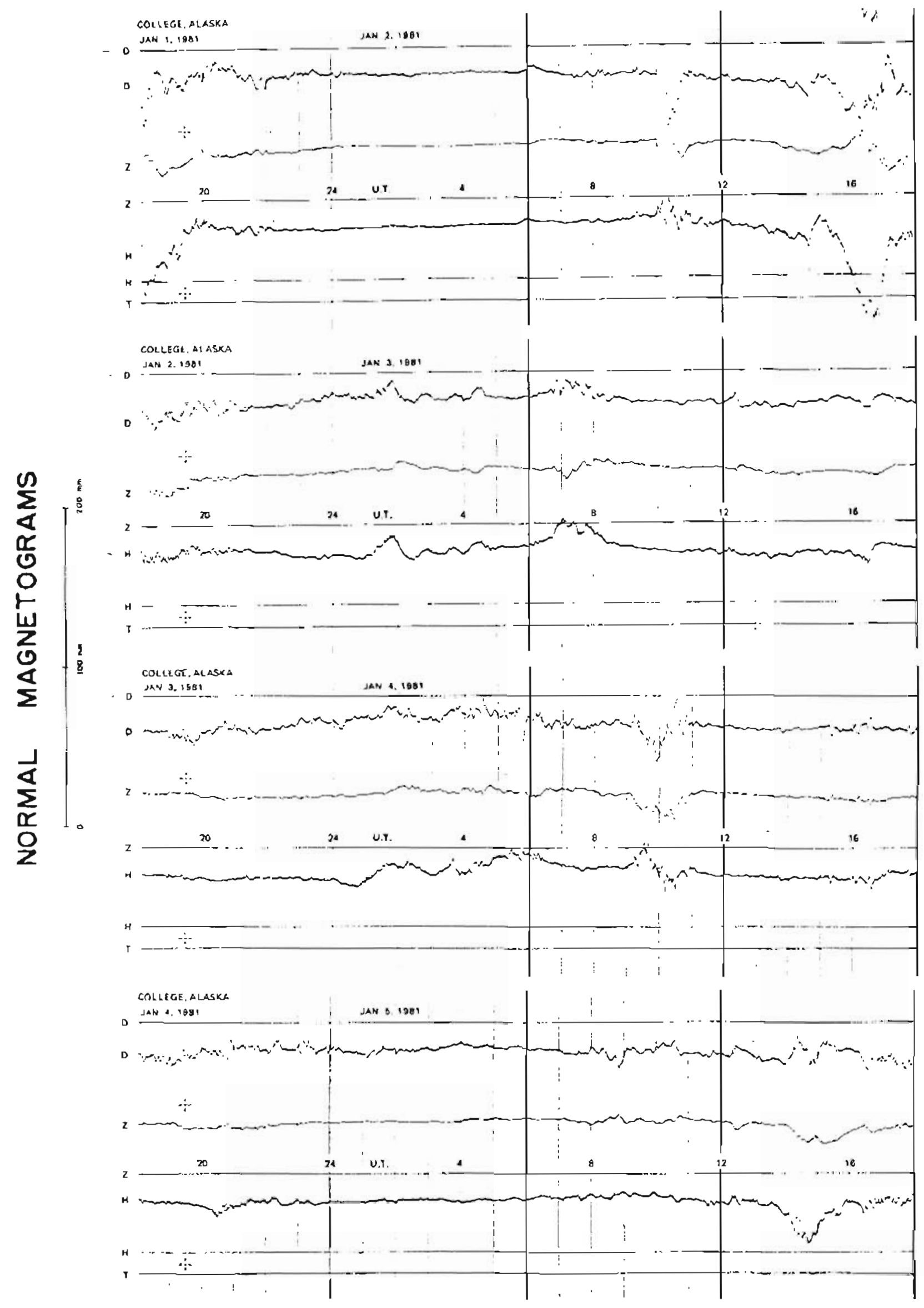




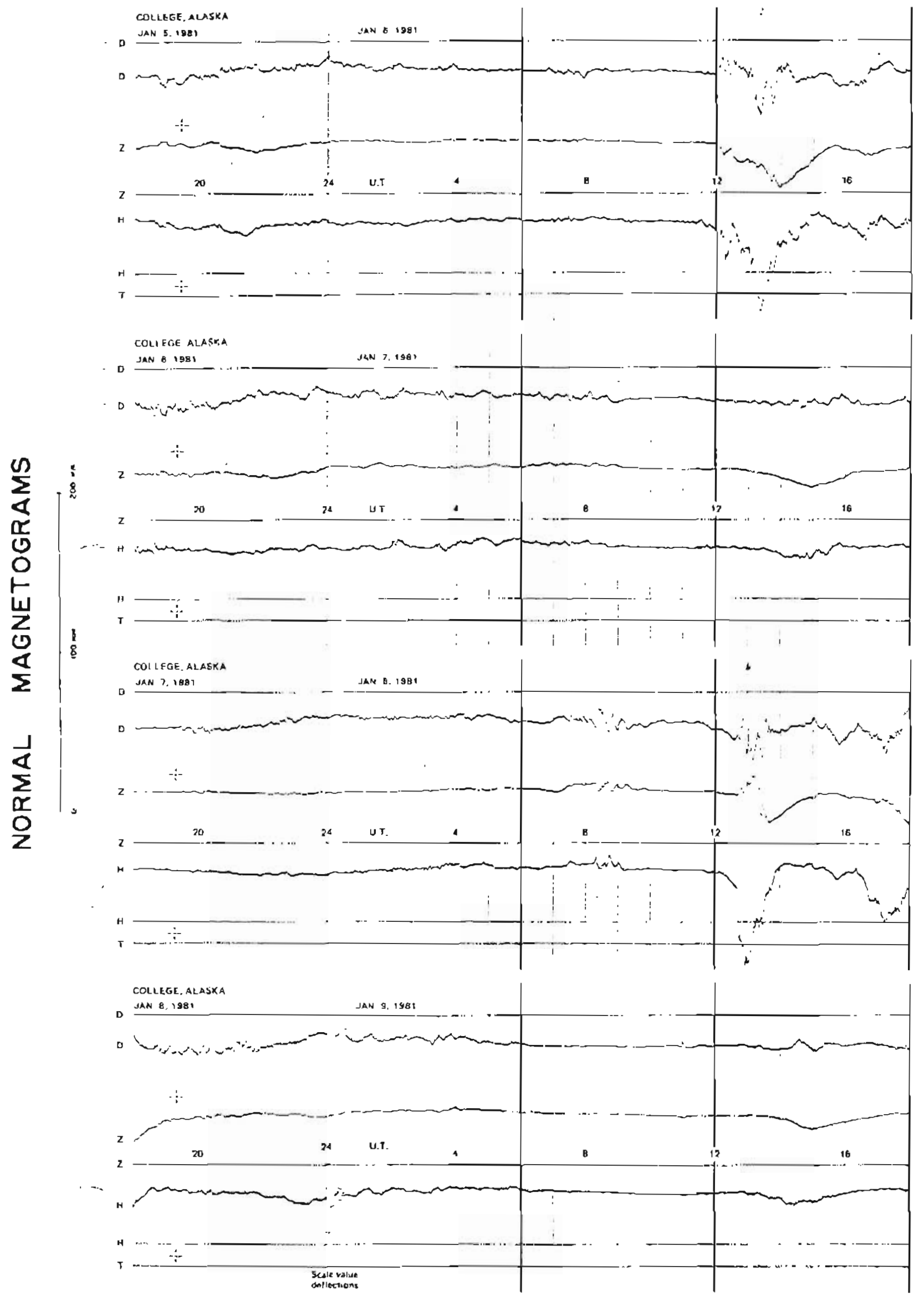




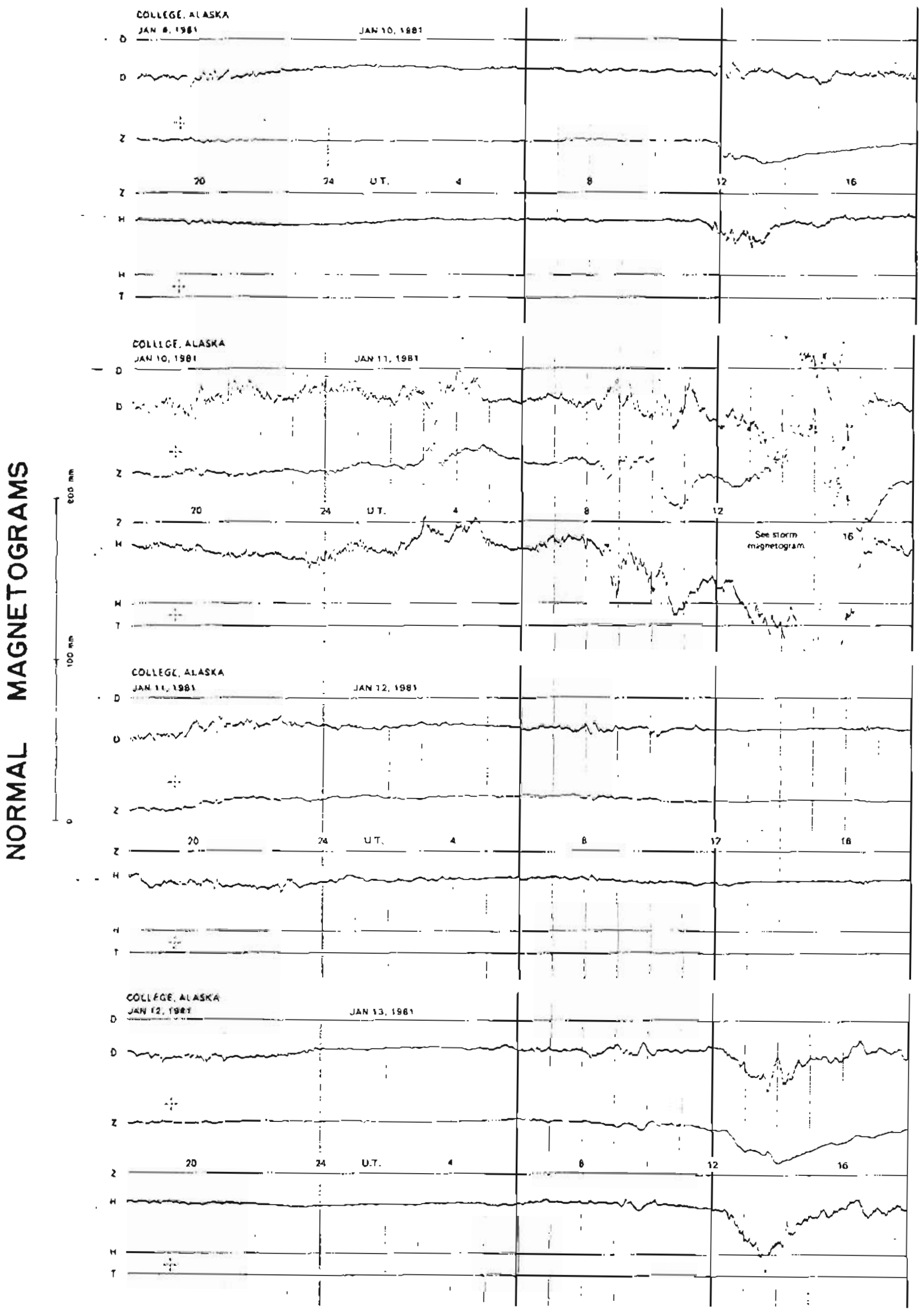




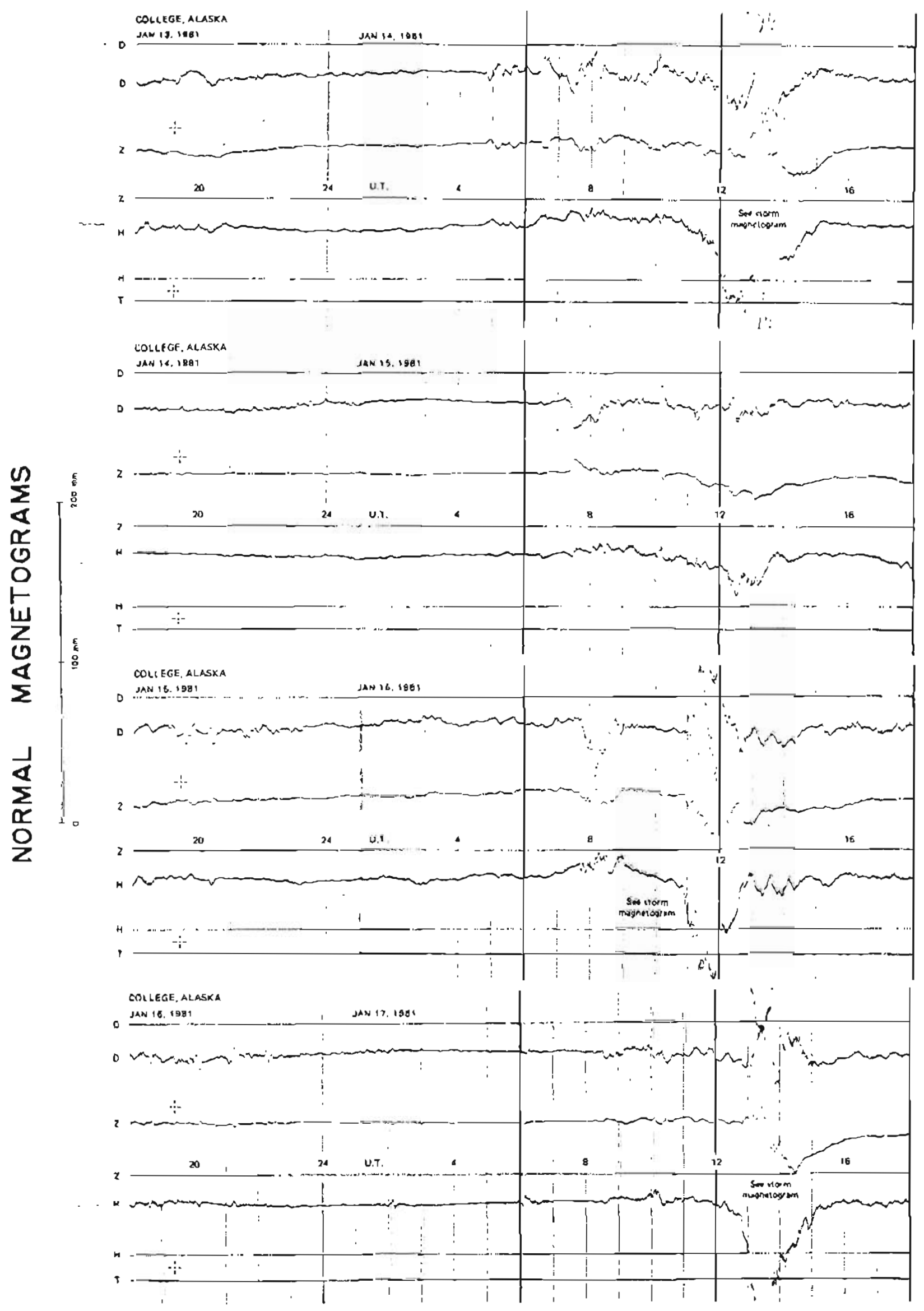




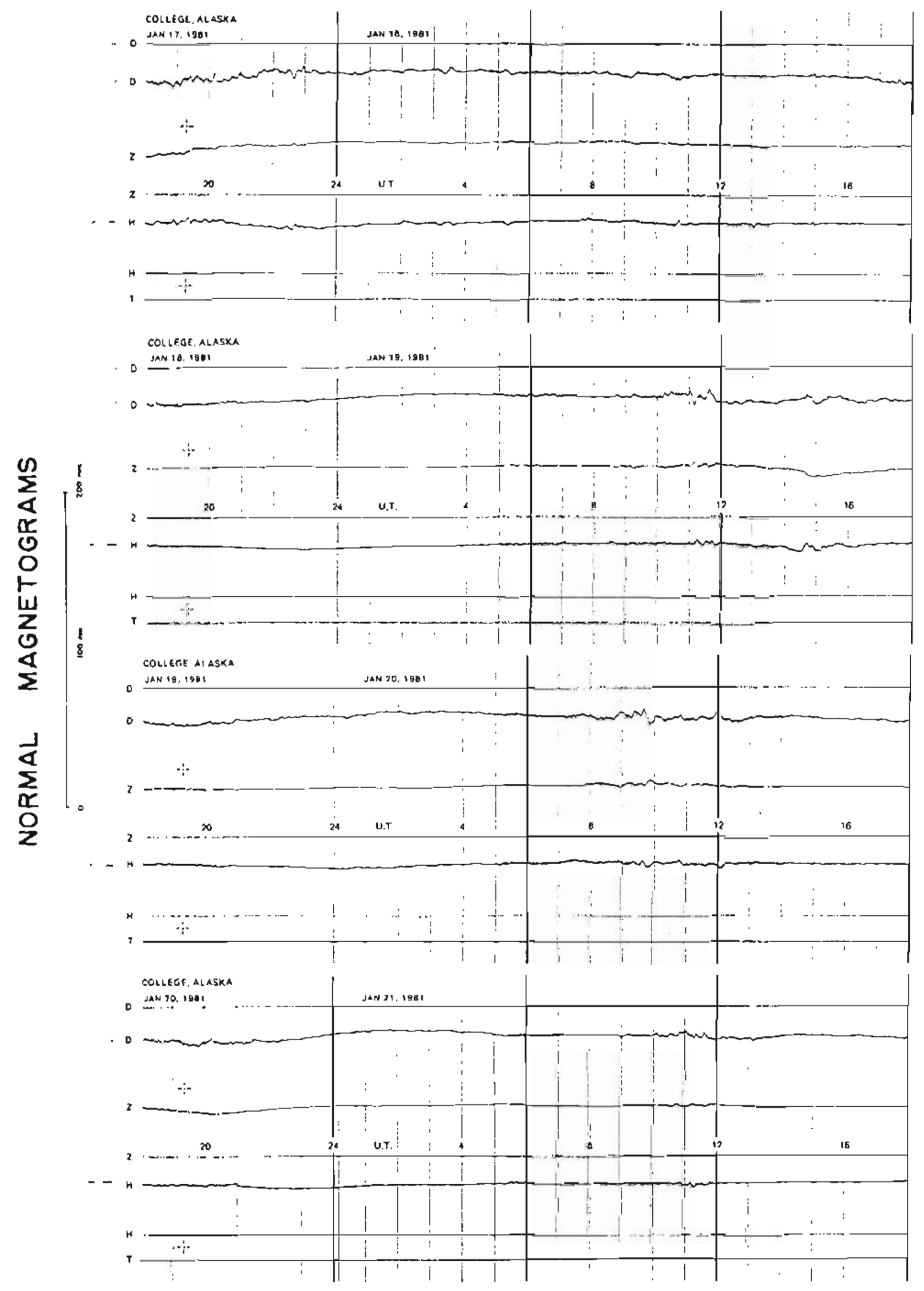




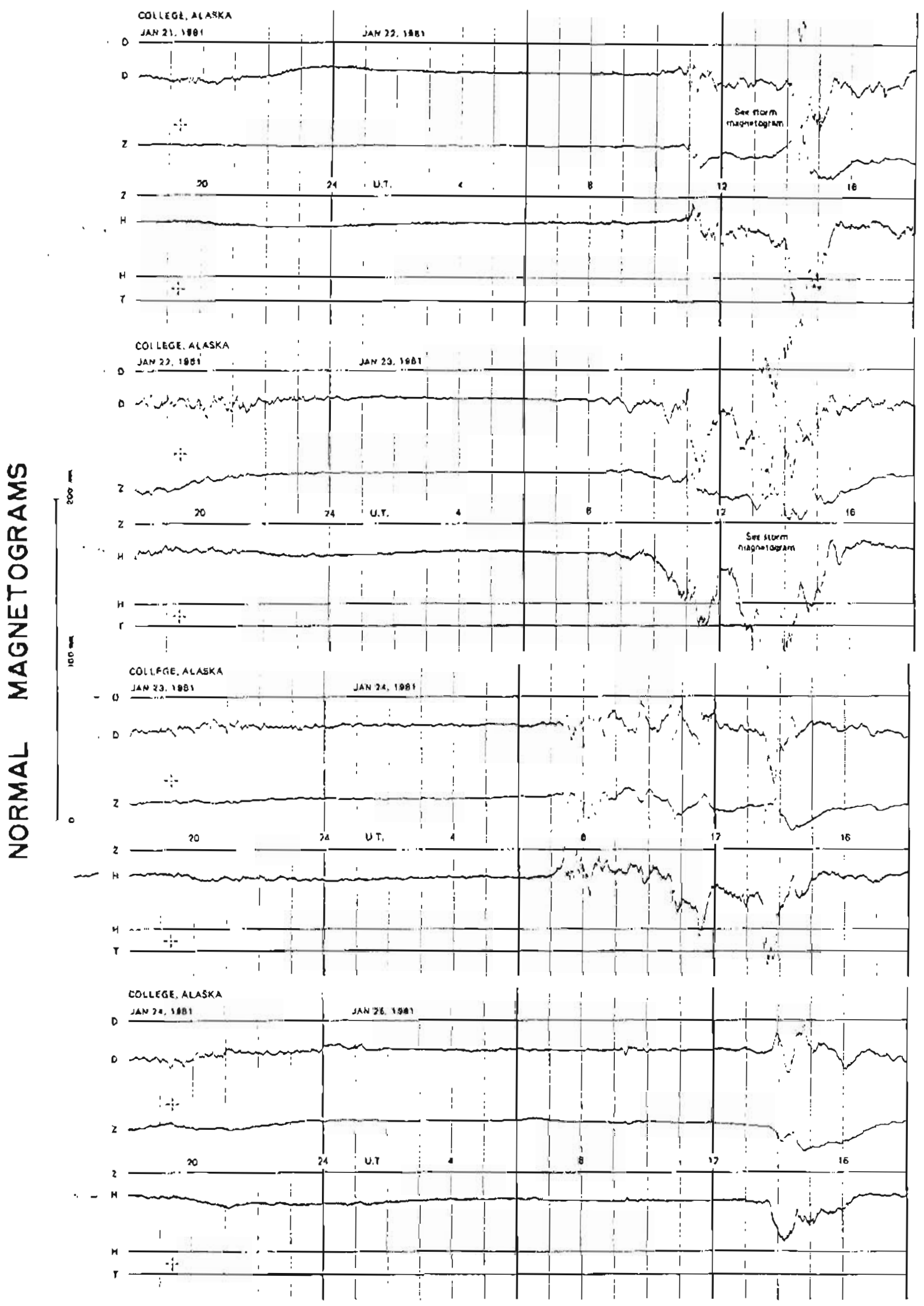




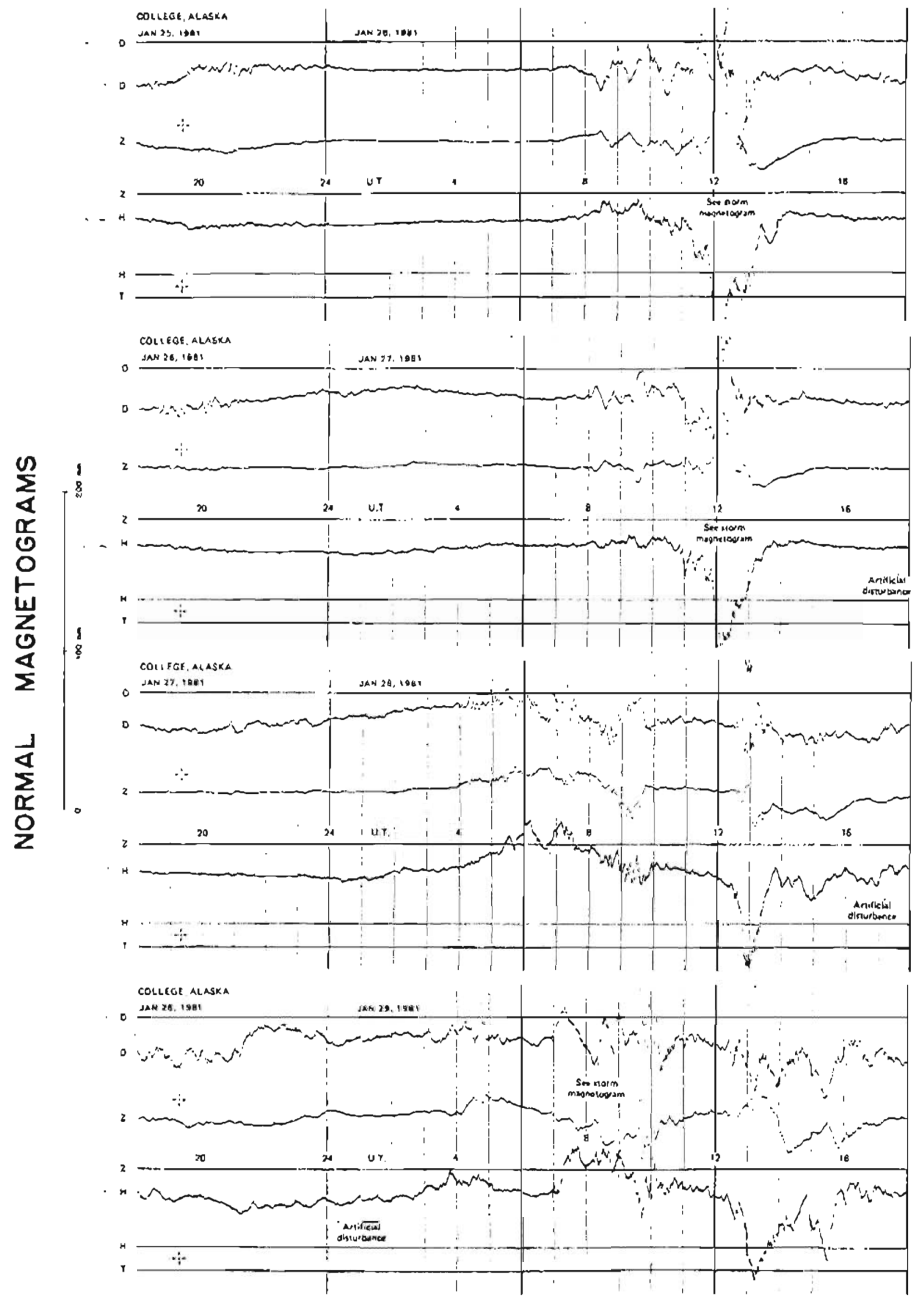




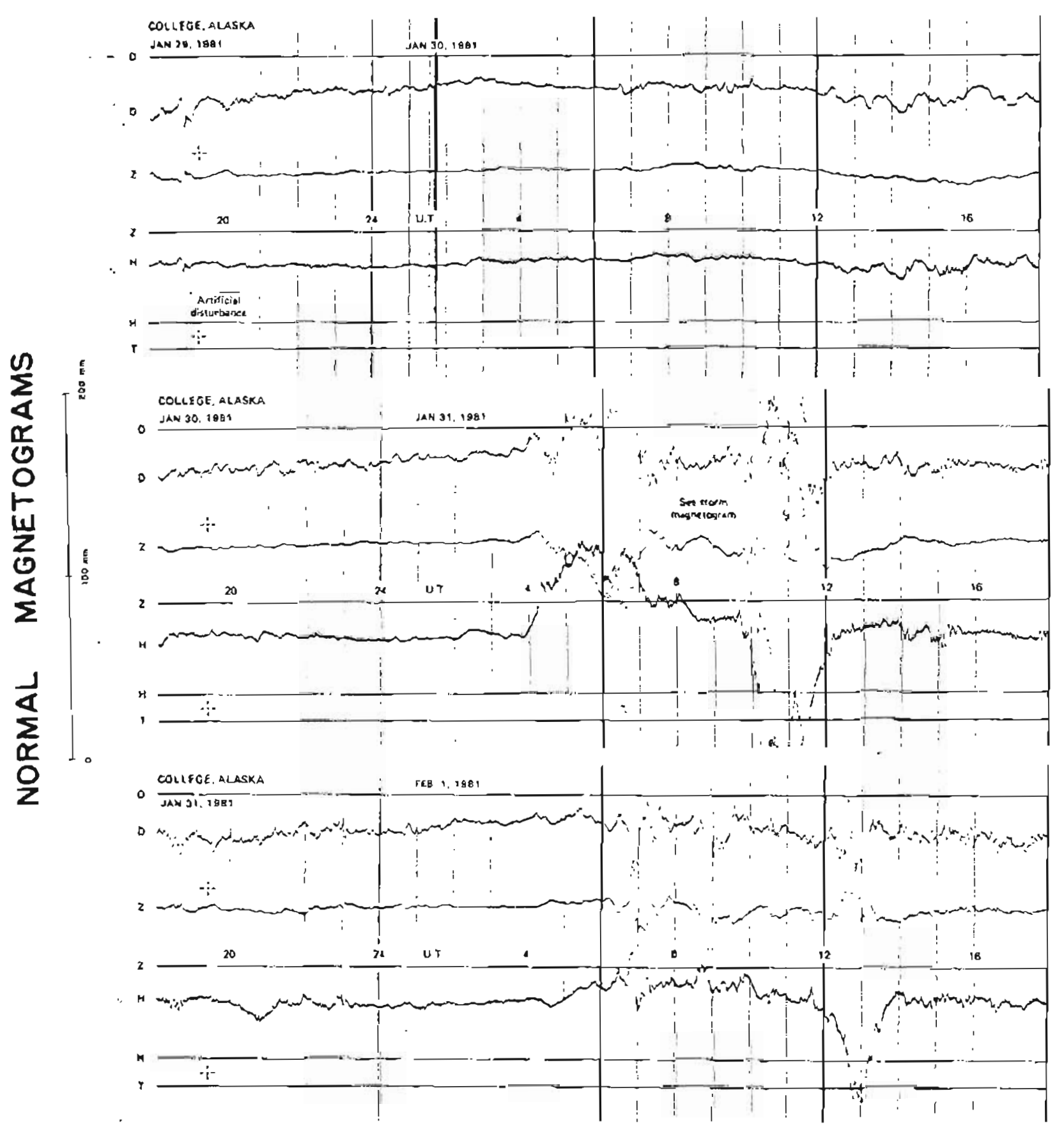



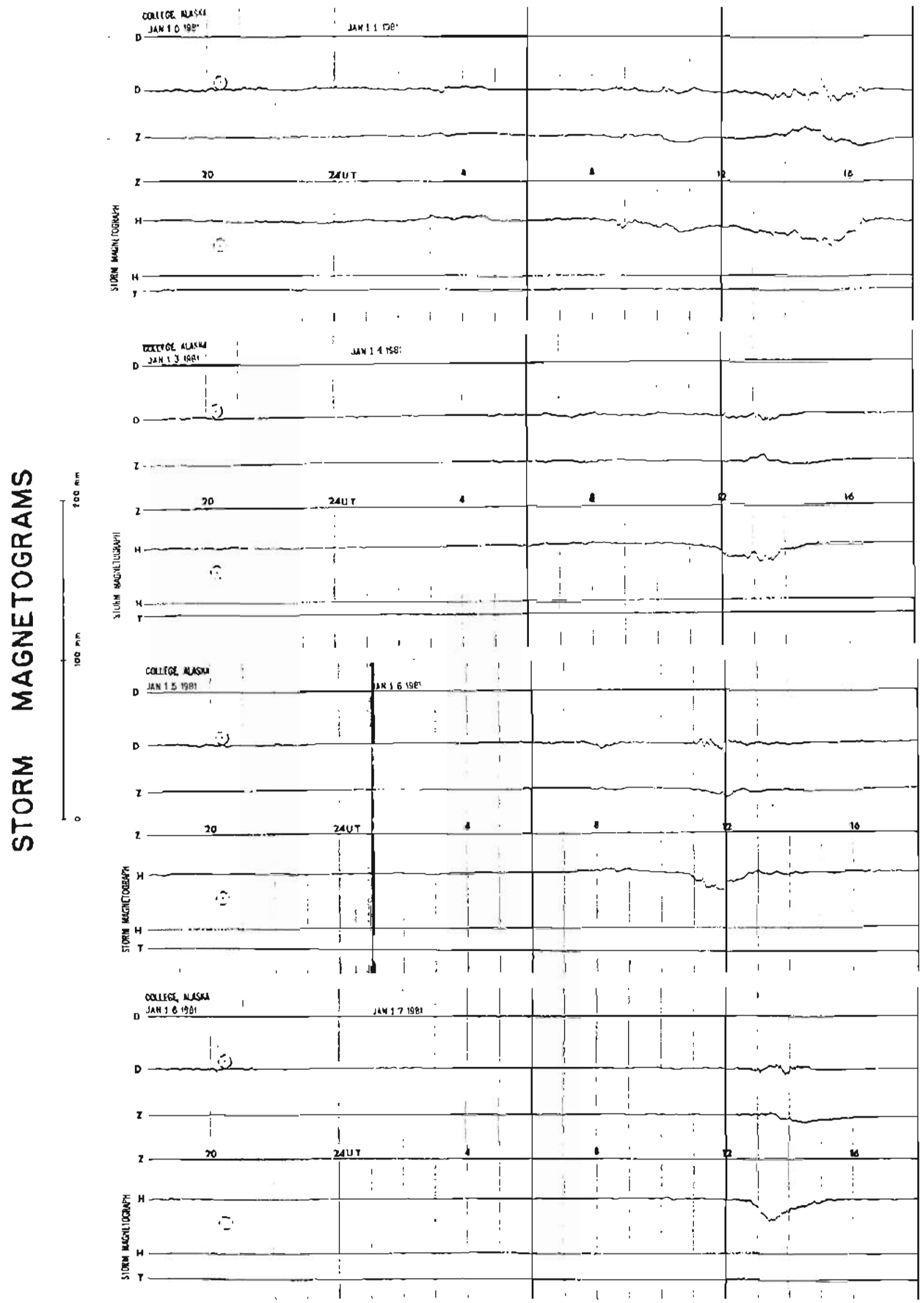


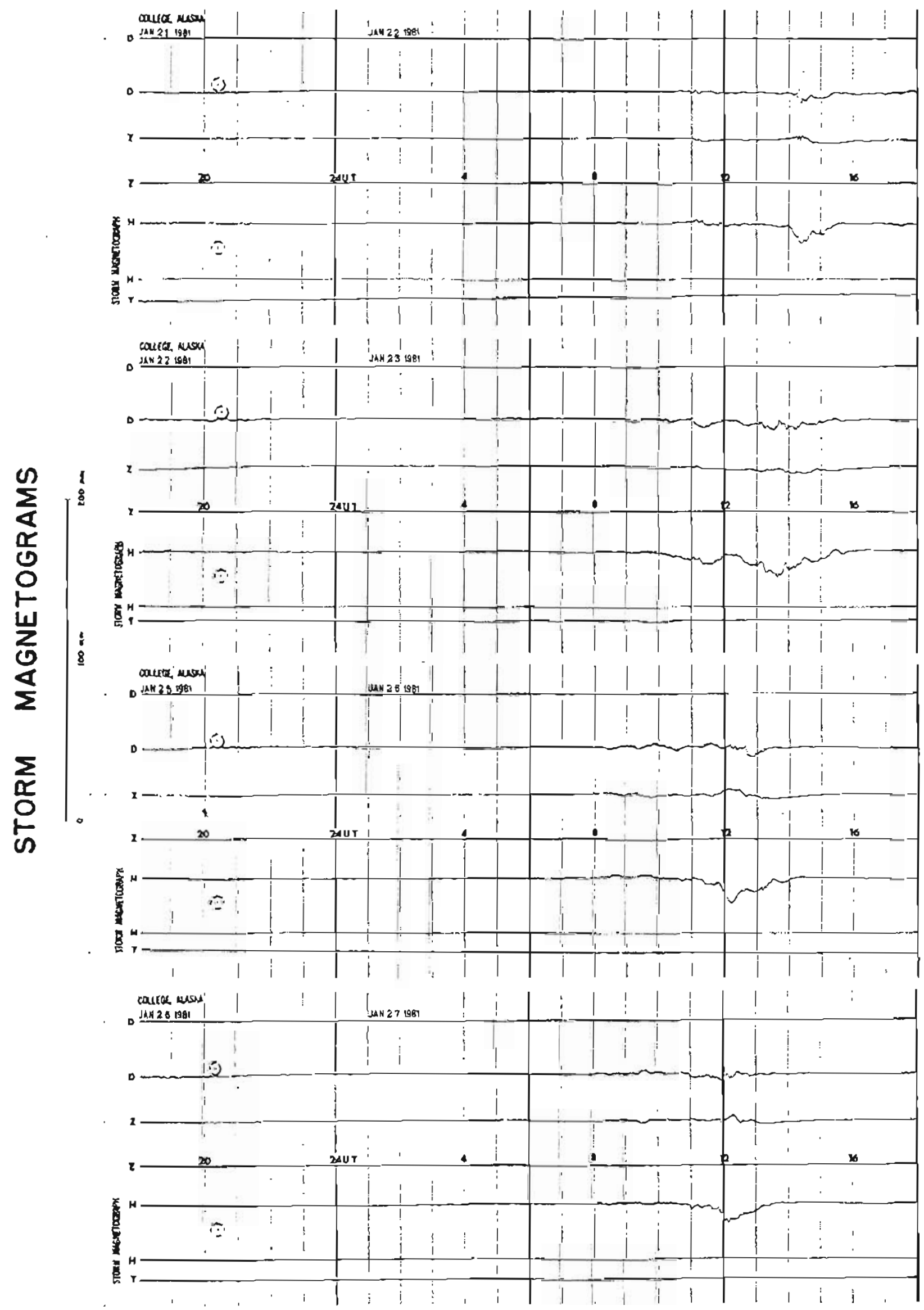




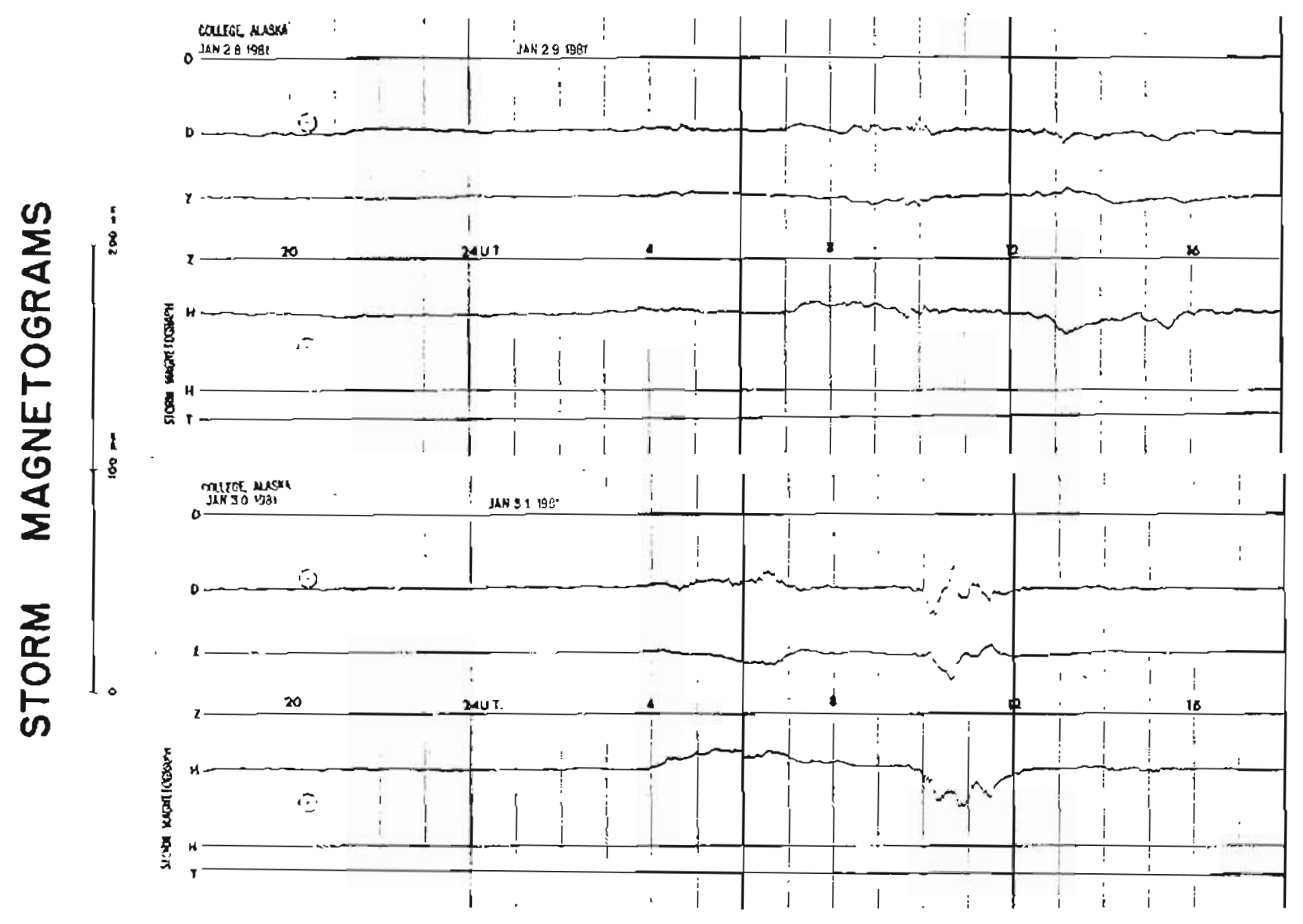

